\title{
Metformin: Hype or Hope for Cancer
}

\author{
Asli NAR \\ Baskent University Faculty of Medicine, Department of Endocrinology and Metabolism, Ankara, TURKEY
}

\begin{abstract}
Current studies show that especially pancreatic, liver, endometrial, colorectal, bladder and breast cancer incidences are increased by the presence of type 2 diabetes mellitus (T2DM). Possible links between T2DM and cancer include hyperinsulinemia, dysregulation of adipocytokines and hyperglycemia as well as shared confounding risk factors. There is evidence emerging from experimental and clinical studies that metformin can play a crucial anti-cancereous role. Since 2005, multiple studies showed the association between metformin and the reduction of risk in cancers of pancreas, colorectal, stomach, liver, breast and esophagus in diabetes cases. It was also claimed to improve survival in some cancers. Metformin is an insulin sensitizer and mainly acts through inhibiting hepatic gluconeogenesis by activating LKB1/AMP-activated protein kinase (AMPK). Metformin was found to have anti-cancerous and antimetastatic effects mainly through activating AMPK dependent and independent signaling; inhibiting mTOR, MAPK, HER2, NF-KB, IGF signaling pathways and with its possible immuno-modulatory effects. Further studies are needed to evaluate the potential of metformin as adjuvant therapy for cancer especially in non-diabetic patients.
\end{abstract}

Keywords: Type 2 diabetes mellitus, Cancer, Metformin

\section{ÖZET}

\section{Metforminin Kanserdeki Muhtemel Rolü: Aldatmaca mı Yoksa Gerçek bir Umut mu?}

Son dönemde yapılan çalışmalar, tip 2 diabetes mellitus (T2DM) varlığında özelllikle pankreas, karaciğer, endometrium, kolorektal, mesane ve meme kanseri insidanslarının arttığını göstermektedir. T2DM ve kanser arasındaki muhtemel bağlantılar; hiperinsülinemi, adipositokinlerin regülasyonunda sorunlar ve hiperglisemi ile birlikte paylaşılan karıştıııı risk faktörlerini kapsamaktadır. Deneysel ve klinik çalışmalar metforminin çok önemli anti-kanseröz etkileri olduğunu ispatlamaktadır. 2005'den itibaren yapılan çok sayıda çalışma, diyabetik olgularda metformin ile pankreas, kolorektal, mide, karaciğer, meme ve ösefagus kanser riskinde azalma arasında ilişkiyi göstermiștir. Bazı kanserlerde sürviyi arttırdığı da iddia edilmektedir. Metformin, bașlıca etkisini LKB1/AMP-activated protein kinase (AMPK) aktivasyonu aracılığı ile hepatik glukoneogenezi inhibe ederek insülin duyarıı̆ı̆ını arttıran bir ilaçtır. Metforminin, AMPK bağımlı ve bağımsız sinyaller aracılı̆ı ile mTOR, MAPK, HER2, NF-кB, IGF sinyal yolaklarını inhibe ederek ve muhtemel immün-modülatuvar etkileri ile anti-kanseröz ve anti-metastatik etkiler gösterdiği saptanmıştır. Adjuvan kanser tedavisinde, özellikle diyabetik olmayan hastalarda metforminin etkilerini değerlendirmek için daha fazla çalışmaya gereksinim vardır.

Anahtar Kelimeler: Tip 2 diabetes mellitus, Kanser, Metformin 


\section{TYPE 2 DIABETES MELLITUS and CANCER}

Type 2 diabetes mellitus (T2DM) was studied in relation to risk of cancer and strong associations were claimed. Impact of diabetes on cancer incidence and mortality was detected in meta-analyses and observational studies. ${ }^{1,2}$ Current researches show that especially pancreatic, liver, endometrial, colorectal, bladder and breast cancer incidences are increased by the presence of diabetes. ${ }^{3,4}$

Multiple and complex mechanisms were postulated for the association between diabetes and cancer. These associations could be causal or because of common risk factors since type 2 diabetes and cancer are common chronic disorders. Cancer is the second and T2DM is the tenth leading cause of mortality in the latest global, regional and countrylevel cause-specific mortality estimates for the year 2015. ${ }^{5}$ There are also several shared confounding risk factors like age, sex, smoking, obesity, genetics, diet and sedentary lifestyle. ${ }^{6}$ Interrelation between these factors usually can not be assessed.

\section{Possible Links Between Type 2 Diabetes Mellitus and Cancer}

\section{Hyperinsulinemia}

Hallmark of type 2 diabetes mellitus is desensitization of target tissues to the actions of insulin which is called insulin resistance. This leads to compensatory increase in insulin production causing hyperinsulinemia. Insulin is known for its mitogenic properties. ${ }^{7}$ In previous studies, hyperinsulinemia was found to be linked with the occurance of the breast, colon, liver, esophagus, pancreas and endometrium cancers. ${ }^{8}$

The known metabolic and mitogenic effects of insulin are mediated by insulin receptors (InsR). There are two isoforms of InsR: InsRA and InsRB. InsRB regulates metabolic effects of insulin in peripheral target tissues. InsRA binds insulin, insulinlike growth factor II (IGF-II) and proinsulin thus involved in mitogenic activities. ${ }^{7}$ InsRA is found to be overexpressed in cancers of breast, lung, thyroid, endometrium and ovaries. ${ }^{9}$

IGF-1 was found to be increased in response to hepatic stimulation of insulin. ${ }^{10}$ Insulin also increases
IGF-1 via decreasing the production of IGF binding protein and inhibiting IGF-1 binding to other binding proteins. ${ }^{10}$ IGF-1 receptor is activated by insulin, IGF-1 and IGF-II, which is also involved in mitogenic signaling and tumor development. IGF1 stimulates MAPK/ERK and PI3K/Akt/mTOR (Phosphatidylinositol-3 kinases/Akt/ mammalian target of rapamycin) signaling pathways and inhibits PTEN (Phosphatase and tensin homolog deleted on chromosome 10) which leads to antiapoptotik activity. ${ }^{10}$ Some neoplastic cells generate hybrid insulin/IGF-1 receptors activated by insulin, IGF-1 and IGF-2. In addition, chronic hyperinsulinemia leads to excessive growth of and progression to cancer by increasing glucose utilization. Nowadays, it is widely accepted that malignant transformation generally involves hyperactivation of insulin, mTOR signaling pathway and genetical aberrations in metabolic signaling pathways. ${ }^{10}$

\section{Adipocytokines}

Adipose tissue is an important endocrine organ which releases adipokines and sex hormones. In addition to direct effect of insulin, other pathways involved in central adiposity also induce malignant progression. The cytokines derived from adipose cells like tumor necrosis factor (TNF)-alpha, resistin and interleukin IL- 6 cause chronic inflammation and insulin resistance leading to malignant transformation (11). In addition, adipose tissue releases VEGF (Vascular Endothelial Growth Factor) and MMPs (Matrix Metalloproteinases) which are involved in tumor angiogenesis and metastasis. ${ }^{11}$

The expression of adipocytokines are dysregulated in obesity. Leptin has pro-inflammatory effects and increases insulin resistance by $\mathrm{ObR}$ and $\mathrm{LRb}$ receptors. Signaling pathways activated (PI3K, MAPK and STAT) cause angiogenesis, mitogenesis and suppression of apoptosis. ${ }^{11}$

Another adipokine secreted from adipocytes called adiponectin, on the other hand, inhibits cell proliferation and induces apoptosis. ${ }^{11}$ It activates AMPK signaling pathway which leads to inhibition of $\mathrm{PI} 3 \mathrm{~K} / \mathrm{AKT} / \mathrm{mTOR}$ signaling.

Insulin was reported to cause increased androgen production from the ovaries and adrenal gland. ${ }^{11}$ 
Besides that adipocytes secrete aromatase enzyme that cause conversion of androgens to estradiol. Insulin also decreases sex hormone binding globulin (SHBG) which results in high levels of circulating estradiol. It was hypothesized that this high estradiol levels caused by hyperinsulinism may lead to hormone sensitive cancers, like breast or endometrium cancers. ${ }^{11}$

\section{Hyperglycemia}

Hyperglycemia itself was also proposed to induce carcinogenesis by causing oxidative stres through DNA damage. ${ }^{12}$ The cancer and normal cells mainly differ according to their glucose consumption levels. The mutations that induce cancer sometimes affect glucose uptake pathways and result in a shift from mitochondrial oxidative phosphorylation to aerobic glycolysis, which is named Warburg effect. ${ }^{12}$ In that case, cancer cells produce lactate from glucose even under hypoxic and low nutrient conditions as the major energy producing mechanism. The oncogenic mutations in HIF-1 (Hypoxia inducible factor-1) and PI3K/Akt/mTOR phosphoinositide 3-kinase/protein kinase $\mathrm{B} /$ mammalian target of rapamycin (PI3K/Akt/mTOR) pathways affect glucose uptake system through Warburg effect causing abnormal growth. ${ }^{12}$

\section{Insulin Treatment and CancerRisk}

It is assumed that insulin treatment may increase the risk of cancer by stimulatig related receptors. Several observational reports in 2009 claimed that a long acting insulin analogue, glargine, may cause increased risk of cancer, specifically breast cancer. ${ }^{13,14}$ A conclusion was made as method and time related biases may have caused this apparently increased cancer risk. ORIGIN trial assigning 12.537 patients to standard care versus insulin glargine concluded that there was no risk increment for specific cancer types between the groups. ${ }^{15}$

\section{METFORMIN AND CANCER}

Metformin is presently the first line recommended medication in T2DM. ${ }^{16}$ It is now found to have anti-cancerous effects mainly by targeting cancer signaling pathways.
In 2005, it was firstly reported that cancer incidence was lower with metformin usage in patients with type 2 diabetes than those taking other antidiabetic medications. ${ }^{17}$ They found $23 \%$ decrease in risk of cancer in their retrospective study. Since then, multiple studies showed the association between metformin and the reduction of risk in cancers of pancreas, colorectal, stomach, liver, breast and esophagus in diabetes cases. ${ }^{18}$ Metformin was also claimed to improve survival in some cancers such as breast, pancreas, ovarian, colorectal, endometrial, esophagus and prostate cancers. ${ }^{19}$ In a study published in 2013, metformin was found to increase 5-year survival in breast cancer and T2DM patients. ${ }^{20}$ Metformin was shown to reduce cancer risk of $31 \%$ and cancer mortality of $34 \%$ in a recent meta-analysis. ${ }^{21}$

In an another recent meta-analysis which included 265 studies, metformin or glitazones were linked with lower incidence of cancer but; oral antidiabetic medications called sulfonylureas, insulin and alpha-glucosidase inhibitors were linked with increased incidence of cancer ( $R R=0.86,0.93$ vs $1.20,1.21,1.10$ respectively). ${ }^{22}$

Metformin was approved in Europe in 1958 and in USA in 1995 for use in type 2 diabetes mellitus which is an insulin sensitizer and mainly acts through inhibiting hepatic gluconeogenesis by activating LKB1 (liver kinase B1)/AMP-activated protein kinase (AMPK) ${ }^{23}$ It also stimulates peripheral glucose uptake by target tissues. This reduction in hepatic gluconeogenesis causes a reduction in hyperinsulinemia. This effect is supposed to decrease stimulation of IR-A, ultimately inhibiting cancer cell growth. ${ }^{24}$ Metformin was also found to inhibit IGF-1R and IR gene expressions demonstrated in endometrial cancer cell lines and breast cancer patients. ${ }^{25}$

\section{Proofs for the Anti-cancerous Activity of Metformin}

In diabetic patients who use metformin, pancreas cancer risk was found to be decreased significantly in female patients in comparison to patients who didn't use metformin. ${ }^{26}$

Metformin use -after pancreatic cancer operation- resulted in a median survival of 35.5 months 
in comparison to 20.2 months in non-users (HR $0.668,95 \%$ CI $0.397-1.125) .{ }^{27}$

In colorectal carcinoma, metformin caused $44 \%$ reduction in all-cause mortality and $34 \%$ in risk of mortality. ${ }^{28}$ In colon cancer cells, metformin was demonstrated to increase apoptosis in p53 deficient cells. ${ }^{29}$

In postmenopausal women with diabetes, metformin was found to have protective effect on breast cancer risk (OR 0.83, 95\% CI 0.71-0.97). ${ }^{30}$ Stronger associations were found when analyses were limited to studies estimating the impact of longer metformin use ( $\mathrm{OR}=0.75 .95 \% \mathrm{CI} 0.62,0.91)$. In early stage breast carcinoma, diabetic patients who were on metformin and neoadjuvant chemotherapy had beter pathological response compared to diabetics who did not use metformin (24\% vs $8 \%){ }^{31}$ Metformin was found to cause $44 \%$ reduction in prostate cancer risk in caucasian diabetic men. ${ }^{32}$

In diabetic women, metformin was suggested to decrease ovarian cancer incidence. ${ }^{33}$ It was also noticed that metformin enhanced the anti-neoplastic effect of cisplatin in epithelial ovarian cancer cell lines. ${ }^{34}$

Some previous studies suggested that metformin causes a decreased incidence of lung cancer and increased the remission period. ${ }^{35,36}$ In mice with lung cancer, metformin inhibited the AKT and mTOR pathways resulting in $72 \%$ reduction in tumor load. ${ }^{37}$

Preclinical studies show that metformin inhibits endometrial, ovarian and glioma cells. ${ }^{34,38,39}$ Metformin also causes decreased hepatocellular cancer incidence in diabetic patients. ${ }^{40}$ In hepatocellular cancer cells, metformin was found to decrease mitochondrial oxygen consumption and suppress hypoxia induced HIF-1 alpha accumulation which was shown to be involved in the development of hepatocellular cancer. ${ }^{41}$

In the non-diabetic cancer patients, metformin also shows good promises. In colorectal cancer, metformin addition to chemotherapy resulted in disease stabilization. ${ }^{42}$ Metformin reduces colorectal cancer risk probably through its local effect after oral intake in addition to its apoptotic effect in p53 deficient cells.
In a non-diabetic patient group of 102 women with breast cancer, metformin treated group $(1700 \mathrm{mg} /$ day) in addition to 6 months of hormonal treatment, had significantly less metastasis. ${ }^{43}$ Metformin also caused significant reduction of IGF-1, insulin, and HOMA-IR and significant increase of IGFBP-3 which is known as apoptosis inducer. ${ }^{43}$

Table 1 summarizes in vivo and in vitro studies that prove anticancerous effects of metformin in different types of cancer.

\section{Possible Mechanisms of Anti-cancerous Activity of Metformin}

Metformin exhibits its anticancerous effects by inhibiting insulin resistance and some growth factors like mTOR (mammalian target of rapamycin), FASN and SREBP-1 through AMPK-dependent and independent systemic pathways. ${ }^{23}$ AMPK is a serine threonine protein kinase that inhibits protein synthesis and mTOR which is involved in cellular growth. ${ }^{44}$ Metformin activates AMPK by inhibiting complex 1 of mitochondrial respiratory chain, suggesting that metformin's effects are linked to the interference of energy signaling (causing an energy deficient state) and cellular metabolism (reduction of protein transit through nuclear pore complex causing decreased protein synthesis). ${ }^{45}$ Metformin also inhibits cyclin dependent kinases, down regulates cyclin D1 levels and up-regulates p53 to p21 axis. ${ }^{46} \mathrm{LKB} 1$ is a tumor supressor gene which also activates AMPK. Metformin has cytotoxic and cytostatic effects on cancer cells in LKB1/AMPK-dependent or/and independent ways. ${ }^{45}$ AMPK-independent effects of metformin are mediated through a negative regulator of mTOR called REDD1 (regulated in development and DNA damage) by affecting cell cycle arrest and reduction in cyclin D $1 .{ }^{47}$

The appropriate dosage needed to activate AMPK is still not known. ${ }^{48}$ Many in vivo preclinical studies were shown to use extremely higher doses of metformin than antidiabetic doses. ${ }^{24}$ On the other hand, in an in vitro study by Sinnett-Smith J. et al, mTORC 1 activity inhibition by metformin was found to be dose dependent and very low plasma concentrations $(0.05 \mathrm{mM})$ of metformin was effective. ${ }^{49}$ In their study, they demonstrated that met- 


\begin{tabular}{|c|c|c|c|}
\hline Cancer type/model & Result & T2DM & References \\
\hline Any & $23 \% \downarrow$ in risk of cancer & + & 17 \\
\hline Any & $31 \% \downarrow$ in risk of cancer $34 \% \downarrow$ in cancer mortality & + & 21 \\
\hline Any & $\downarrow$ in risk of cancer: $\mathrm{RR}=0.86,95 \% \mathrm{Cl} 0.83-0.90, \mathrm{I} 2=88.61 \%$ & + & 22 \\
\hline Pancreas & $\downarrow$ in risk in women, adj. OR: 0.43, 95\% Cl: 0.23-0.80 & + & 26 \\
\hline After pancreatectomy & 个survival of 35.5 m vs 20.2 m, HR 0.668, 95\% Cl 0.397-1.125 & + & 27 \\
\hline \multirow[t]{2}{*}{ Colorectal } & $34 \% \downarrow$ in risk of mortality & + & 28 \\
\hline & Disease stabilization & - & 42 \\
\hline Colon cancer cells & $\uparrow$ apoptosis & - & 29 \\
\hline \multirow[t]{5}{*}{ Breast } & $\uparrow 5$-year survival & + & 20 \\
\hline & $\downarrow$ breast cancer risk in postmenopausal women & + & 30 \\
\hline & $(\mathrm{OR}=0.75 .95 \% \mathrm{Cl} 0.62,0.91)$ & & \\
\hline & $\begin{array}{l}\uparrow \text { pathological response when added to neoadjuvant chemotherapy } \\
\qquad(24 \% \text { vs } 8 \%)\end{array}$ & + & 31 \\
\hline & $\downarrow$ numbers of metastatic cases, $\downarrow$ IGF- $1, \uparrow$ IGFBP-3 & - & 43 \\
\hline Prostate & $44 \% \downarrow$ in risk of prostate cancer & + & 32 \\
\hline Ovarian & $\begin{array}{l}\downarrow \text { ovarian cancer risk (OR 0.61, Cl 0.30-1.35), } \\
\uparrow \text { survival ( } 5 \text { yr) to } 63 \% \text { vs } 23 \%\end{array}$ & + & 33 \\
\hline Ovarian cancer cell lines & $\begin{array}{l}\text { Dose- time-dependent growth inhibition of OVCAR-3, } \\
\text { OVCAR-4 cell lines and potentiated effect of cisplatin }\end{array}$ & - & 34 \\
\hline \multirow[t]{2}{*}{ Lung } & $\uparrow$ overall survival in NSCLC: 20.0 months vs 13.1 months & + & 35 \\
\hline & $\downarrow$ lung cancer risk of $39 \%-45 \%$ & + & 36 \\
\hline $\begin{array}{l}\text { Glioma (stem like glioma } \\
\text { initiating cells) }\end{array}$ & $\begin{array}{l}\downarrow \text { self-renewal capacity, induces differentiation, } \\
\downarrow \text { tumor-initiating potential of stem-like glioma-initiating cells }\end{array}$ & - & 38 \\
\hline Endometrial cancer cell lines & $\downarrow$ cell proliferation in a dose-dependent manner & - & 39 \\
\hline Liver & $\downarrow$ cancer risk, OR: $0.30, \mathrm{Cl}: 0.17,0.52$ & + & 40 \\
\hline \multirow[t]{2}{*}{ HCC cell line } & $\downarrow$ hypoxia-induced $\mathrm{HIF}-1 \alpha$ protein content by promoting & & \\
\hline & protein degradation, $\downarrow$ mitochondrial oxygen consumption & - & 41 \\
\hline
\end{tabular}

formin induced mTORC1 inhibition is greater in physiological glucose concentrations than supraphysiological glucose levels in vitro. This means hyperglycemic states may mask the effect of metformin. This condition is in line with metformin's ability to suppress mitochondrial respiration causing an energy crisis in the cancer cells.

Emerging studies report that metformin also suppresses IGF signaling pathway which may be an another anti-cancerous effect of the medication. The mechanism here could be indirectly by inhibiting insulin, insulin binding proteins thus inhibiting hyperinsulinism and by decreasing IGF-1 induced avtivation of $\mathrm{AKt} / \mathrm{mTOR}$ and $\mathrm{G}$ protein coupled receptor signaling. ${ }^{50}$

Metformin was also reported to activate MAPK signalling pathway (JNK) resulting in apoptosis mediated effect and cell cycle arrest. ${ }^{51}$ 
In human breast cancer cells, metformin was found to suppress overexpressed HER2 (human epidermal growth factor receptor 2) pathway by AMPK independent way. ${ }^{52}$

Metformin was suggested to have anti-inflammatory effects by decreasing activation of inflammatory factor NF- $\mathrm{k} B$ (nuclear factor kapa B) which is a transcription factor regulating proliferation and cell death. ${ }^{53}$ Possibly this anti-inflammatory effect also contributes to metformin's anti-cancerous effect by growth inhibition and interfering the process of cellular transformation. Metformin -at doses of 0.1 or $0.3 \mathrm{mM}$ in vitro- was shown to inhibit NF$\kappa \mathrm{B}, \mathrm{STAT} 3$ transcription factor (signal transducer and activator of transcription 3), Let-7 microRNA family members, IL- 6 and VEGF until 6 hours, the effect that is supposed to block transformation to cancer cell. ${ }^{53}$

Cancer stem cells (CSCs) are cancer initiating cells which have potential to become a tumor. They were found to be both chemo- and radio-resistant. $^{54}$ In 2009, Hirsch et al. firstly reported that metformin selectively targeted cancer stem cells, directly blocking tumor growth and prolonging remission. ${ }^{55}$ Cancer stem cells are also hypothesized to be involved in resistant metastatic disease. ${ }^{45}$ Cancer stem cells are modulated mainly by mitochondria and metformin's effect of mitochondrial intervention seems also to cause cancer stem cell inhibition. ${ }^{45,55}$ Another mechanism detected is inhibition of Warburg effect by metformin and thus the growth of CSCs. ${ }^{56}$

Epithelial to mesenchymal transition has a very important role in metastasis formation. Metformin was demonstrated to inhibit this transition through blockage of mTOR signaling. ${ }^{57}$

Metformin may also have immuno-modulatory effects shown in animal studies. It was reported to inhibit apoptosis of CD8+ tumor infiltrating lymphocytes and CD8+ tumor induced lymphocytes and increases CD8+ memory T cells..$^{58,59}$

Some studies suggested that metformin may sensitize cancer cells to some chemotherapy agents, including cisplatin, doxorubicin and paclitaxel. ${ }^{34,55,60}$ Metformin was also found to increase radiosensitivity of cancer cells through ATM and AMPK. ${ }^{61}$
Metformin was found to cause changes in the composition of intestinal microbiota. Increasing number of studies show that intestinal microbiota has a crucial role in the maintanance of immune system. Previous reports provide a link between alterations of the microbiota in the gastrointestinal system and obesity, type 2 diabetes mellitus, metabolic syndrome, cancer and aging. ${ }^{6}$ Metformin increases the abundance of Akkermansia, a mucus-degrading gram-negative bacteria in the gut, which is associated with restoration of reduced regulatory $\mathrm{T}$ cells and amelioration of low-grade tissue inflammation in the adipose tissue of obese animals. ${ }^{63}$ This effect of metformin on intestines probably causes anti-aging and anti-cancerous effects and life span extension, the effects which need verification. ${ }^{64}$

The North American Breast Cancer Group is executing a placebo-controlled and randomised phase III trial in 3649 non-diabetic women with early stage breast cancer to see the utility of metformin in breast cancer which was planned for 5 years. ${ }^{65}$ Early results show reduction in insulin resistance $(-17.1 \%)$ and inflammatory markers. There are 3 clinical studies currently evaluating survival benefit of metformin in breast cancer but the results are not obtained yet. ${ }^{59}$ The long-term results of these studies may clear up the utility of metformin in cancer treatment.

Clinical trials showed low incidence of side effects and dose limiting toxicity with metformin especially in the cases of combinations with chemotherapy agents. ${ }^{66}$

The overall final effects of metformin in cancer seem to increase apoptosis, cell cycle arrest and to inhibit protein synthesis, cell proliferation, metastasis and invasion. ${ }^{67}$ Possible mechanisms causing anti-cancerous effects of metformin are summarized in Figure 1.

In conclusion, wide range of studies indicate that metformin looks like a promising candidate in cancer prevention and treatment. It was also claimed to improve survival in some cancers. Metformin has anti-cancerous and anti-metastatic effects mainly through activating AMPK dependent and independent signaling; inhibiting mTOR, MAPK, HER2, NF-אB, IGF signaling pathways and with its possible immuno-modulatory effects. Further 


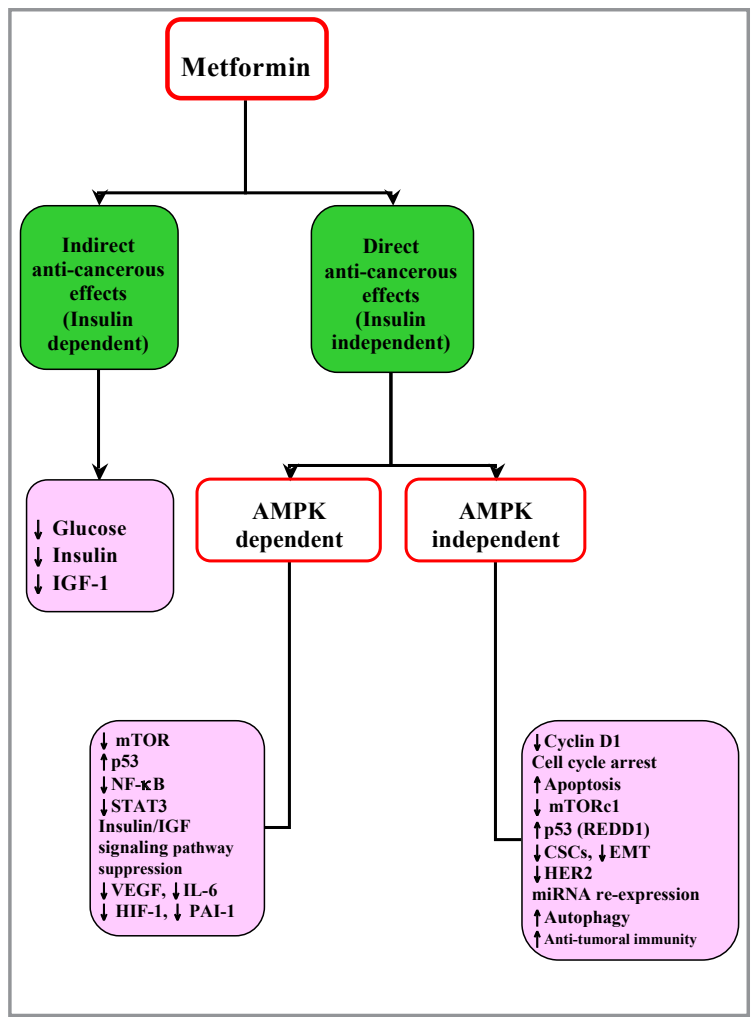

Figure 1. The possible mechanisms underlying anti-cancerous effects of metformin

EMT: Epithelial to mesenchymal transition, CSCs: Cancer stem cells

studies are needed to evaluate the potential of metformin as adjuvant therapy for cancer especially in non-diabetic patients.

\section{REFERENCES}

1. Rapp K, Schroeder J, Klenk J, et al. Fasting blood glucose and cancer risk in a cohort of more than 140000 adults in Austria. Diabetologia 49: 945-952, 2006.

2. Noto H, Tsujimoto T, Sasazuki T, et al. Significantly increased risk of cancer in patients with diabetes mellitus. Endocr Pract 17: 616-628, 2011.

3. Szablewski L. Diabetes mellitus: influences on cancer risk. Diabetes Metab Res Rev 30: 543-553, 2014.

4. Handelsman $\mathrm{Y}$, Leroith D, Bloomgarden ZT, et al. Diabetes and cancer an AACE/ACE consensus statement. Endocr Pract 19: 675-693, 2013.

5. Global Health Estimates 2015: Deaths by Cause, Age, Sex, by Country and by Region, 2000-2015. Geneva, World Health Organization, 2016. (http://www.who.int/healthinfo/ global_burden_disease/en/ (Access date: 12/4/2017)
6. Noto H, Goto A, Tsujimoto T, Osame K, Noda M. Latest insights into the risk of cancer in diabetes. J Diabetes Investig 4: 225-232, 2013.

7. Malaguarnera R, Sacco A, Voci C, et al. Proinsulin binds with high affinity the insulin receptor isoform $A$ and predominantly activates the mitogenic pathway. Endocrinology 153: 21522163, 2012

8. Renehan AG, Tyson M, Egger M, et al. Body-mass index and incidence of cancer: a systematic review and meta-analysis of prospective observational studies. Lancet 371: 569-578, 2008.

9. Parekh N, Guffanti G, Lin Y, et al. Insulin receptor variants and obesity-related cancers in the Framingham Heart Study. Cancer Causes Control 26:1189-1195, 2015.

10. Poloz $\mathrm{Y}$, Stambolic $\mathrm{V}$. Obesity and cancer, a case for insulin signaling. Cell Death Dis 6: e2037, 2015.

11. van Kruijsdijk RC, van der Wall E, Visseren FL. Obesity and cancer: the role of dysfunctional adipose tissue. Cancer Epidemiol Biomarkers Prev 18: 2569-2578, 2009.

12. Jang M, Kim SS, Lee J. Cancer cell metabolism: implications for therapeutic targets. Exp Mol Med 45: e45, 2013.

13. Hemkens LG, Grouven U, Bender R, et al. Risk of malignancies in patients with diabetes treated with human insulin or insulin analogues: a cohort study. Diabetologia 52: 1732-1744, 2009.

14. Jonasson JM, Ljung R, Talback M, et al. Insulin glargine use and short-term incidence of malignancies- a populationbased follow-up study in Sweden. Diabetologia 52: 17451754, 2009.

15. Gerstein HC, Bosch J, Dagenais GR, et al. Basal insulin and cardiovascular and other outcomes in dysglycemia. N Engl $\mathrm{J}$ Med 367: 319-28, 2012.

16. American Diabetes Association. Standards of Medical Care in Diabetes-2017: Summary of Revisions. Diabetes Care 40(Suppl 1): S4-S5, 2017.

17. Evans JM, Donnelly LA, Emslie-Smith AM, et al. Metformin and reduced risk of cancer in diabetic patients. BMJ 330: 1304-1305, 2005.

18. Franciosi M, Lucisano G, Lapice E, et al. Metformin therapy and risk of cancer in patients with type 2 diabetes: systematic review. PLoS One 8: e71583, 2013.

19. Zhang ZJ, Li S. The prognostic value of metformin for cancer patients with concurrent diabetes: a systematic review and metaanalysis. Diabetes Obes Metab 16: 707-710, 2014.

20. Hou G, Zhang S, Zhang X, et al. Clinical pathological characteristics and prognostic analysis of 1,013 breast cancer patients with diabetes. Breast Cancer Res Treat 137: 807-816, 2013.

21. Gandini S, Puntoni M, Heckman-Stoddard BM, et al. Metformin and cancer risk and mortality: a systematic review and meta-analysis taking into account biases and confounders. Cancer Prev Res 7: 867-885, 2014. 
22. Wu L, Zhu J, Prokop LJ, Hassan Murad M. Pharmacologic Therapy of Diabetes and Overall Cancer Risk and Mortality: A Meta-Analysis of 265 Studies. Sci Rep 5: 10147, 2015.

23. Pernicova I, Korbonits M. Metformin-mode of action and clinical implications for diabetes and cancer. Nat Rev Endocrinol 10: 143-156, 2014

24. Dowling RJO, Niraula S, Stamboliv V, Goodwin PJ. Metformin in cancer: translational challenges. J Mol Endocrinol 48: R3143, 2012.

25. Dowling RJ, Niraula S, Chang MC, et al. Changes in insulin receptor signaling underlie neoadjuvant metformin administration in breast cancer: a prospective window of opportunity neoadjuvant study. Breast Cancer Res 17: 32, 2015.

26. Bodmer M, Becker $\mathrm{C}$, Meier $\mathrm{C}$, et al. Use of antidiabetic agents and the risk of pancreatic cancer: a case-control analysis. Am J Gastroenterol 107: 620-626, 2012.

27. Ambe C, Mahipal A, Fulp WJ, et al. Effect of metformin use on the survival outcomes in diabetic patients with resectable pancreatic cancer: a single-institutional experience and review of the literature. PLoS One 11(3): e0151632, 2016.

28. Mei ZB, Zhang ZJ, Liu CY, et al. Survival benefits of metformin for colorectal cancer patients with diabetes: a systematic review and meta-analysis. PLoS One 9: e91818, 2014.

29. Buzzai M, Jones RG, Amaravadi RK, et al. Systemic treatment with the antidiabetic drug metformin selectively impairs p53-deficient tumor cell growth. Cancer Res 67: 6745-6752, 2007.

30. Col NF, Ochs L, Springmann V, et al. Metformin and breast cancer risk: a meta-analysis and critical literature review. Breast Cancer Res Treat 135:639-46, 2012.

31. Jiralerspong S, Palla SL, Giordano SH, et al. Metformin and pathologic complete responses to neoadjuvant chemotherapy in diabetic patients with breast cancer. Clin Oncol 10: 3297-3302, 2009.

32. Wright JL, Stanford JL. Metformin use and prostate cancer in Caucasian men: results from a population-based casecontrol study. Cancer Causes Control 20: 1617-1622, 2009.

33. Febbraro T, Lengyel E, Romero IL. Old drug, new trick: Repurposing metformin for gynecologic cancers? Gynecol Oncol 135: 614-621, 2014.

34. Gotlieb WH, Saumet J, Beauchamp MC, et al. In vitro metformin antineoplastic activity in epithelial ovarian cancer. Gynecol Oncol 110: 246-250, 2008.

35. Tan BX, Yao WX, Ge J, et al. Prognostic influence of metformin as firstline chemotherapy for advanced nonsmall cell lung cancer in patients with type 2 diabetes. Cancer 117: 5103-5111, 2011.

36. Lai SW, Liao KF, Chen PC, et al. Antidiabetes drugs correlate with decreased risk of lung cancer: a population-based observation in Taiwan. Clin Lung Cancer 13: 143-148, 2012.

37. Memmott RM, Mercado JR, Maier CR, et al. Metformin prevents tobacco carcinogen--induced lung tumorigenesis. Cancer Prev Res (Phila) 3:1066-1076, 2010.
38. Sato A, Sunayama J, Okada M, et al. Glioma-initiating cell elimination by metformin activation of FOXO3 via AMPK. Stem Cells Transl Med 1: 811-824, 2012.

39. Cantrell LA, Zhou C, Mendivil A, et al. Metformin is a potent inhibitor of endometrial cancer cell proliferation--implications for a novel treatment strategy. Gynecol Oncol 116: 92-98, 2010.

40. Zhang ZJ, Zheng ZJ, Shi R, et al. Metformin for liver cancer prevention in patients with type 2 diabetes: a systematic review and metaanalysis. J Clin Endocrinol Metab 97: 23472353, 2012

41. Zhou X, Chen J, Yi G, et al. Metformin suppresses hypoxia induced stabilization of HIF-1 $\alpha$ through reprogramming of oxygen metabolism in hepatocellular carcinoma. Oncotarget 7: 873-84, 2016.

42. Thent ZC, Zaidun NH, Azmi F, et al. Is metformin a therapeutic paradigm for colorectal cancer: Insight into the molecular pathway? Curr Drug Targets 18: 734-750, 2016.

43. El-Haggar SM, El-Shitany NA, Mostafa MF, El-Bassiouny NA. Metformin may protect nondiabetic breast cancer women from metastasis. Clin Exp Metastasis 33: 339-357, 2016.

44. Inoki K, Zhu T, Guan KL. TSC 2 mediates cellular energy response to control cell growth and survival. Cell 115: 577-590, 2003.

45. Gong J, Kelekar G, Shen J, et al. The expanding role of metformin in cancer: an update on antitumor mechanisms and clinical development. Target Oncol 11: 447-467, 2016.

46. Algire $\mathrm{C}$, Amrein L, Bazile M, et al. Diet and tumor Ikb1 expression interact to determine sensitivity to anti-neoplastic effects of metformin in vivo. Oncogene 30: 1174-1182, 2011.

47. Sahra IB, Regazzetti C, Robert G, et al. Metformin, independent of ampk, induces mtor inhibition and cell-cycle arrest through redd1. Cancer Res 71(13): 4366-4372, 2011.

48. $\mathrm{He} \mathrm{H}, \mathrm{Ke} \mathrm{R}$, Lin $\mathrm{H}$, et al. Metformin, an old drug, brings a new era to cancer therapy. Cancer J 21: 70-74, 2015.

49. Sinnett-Smith J, Kisfalvi K, Kui R, Rozengurt E. Metformin inhibition of mTORC1 activation, DNA synthesis and proliferation in pancreatic cancer cells: dependence on glucose concentration and role of AMPK. Biochem Biophys Res Commun 430:352-357, 2013.

50. Karnevi E, Said K, Andersson R, Rosendahl AH. Metforminmediated growth inhibition involves suppression of the igf-1 receptor signalling pathway in human pancreatic cancer cells. BMC Cancer 13: 235, 2013.

51. Tseng SC, Huang YC, Chen HJ, et al. Metformin-mediated downregulation of p38 mitogen-activated protein kinasedependent excision repair crosscomplementing 1 decreases DNA repair capacity and sensitizes human lung cancer cells to paclitaxel. Biochem Pharmacol 85: 583-94, 2013.

52. Vazquez-Martin A, Oliveras-Ferraros C, Menendez JA. The antidiabetic drug metformin suppresses her2 (erbb-2) oncoprotein overexpression via inhibition of the mtor effector p70s6k1 in human breast carcinoma cells. Cell Cycle 8: 8896, 2009. 
53. Hirsch HA, lliopoulos D, Struhl K. Metformin inhibits the inflammatory response associated with cellular transformation and cancer stem cell growth. Proc Natl Acad Sci USA 110: 972-977, 2013.

54. Zhou BB, Zhang H, Damelin M, et al. Tumour-initiating cells: challenges and opportunities for anticancer drug discovery. Nat Rev Drug Discov 8(10): 806-823, 2009.

55. Hirsch HA, lliopoulos D, Tsichlis PN, et al. Metformin selectively targets cancer stem cells, and acts together with chemotherapy to block tumor growth and prolong remission. Cancer Res 69: 7507-7511, 2009.

56. Del Barco S, Vazquez-Martin A, Cufí S, et al. Metformin: multi-faceted protection against cancer. Oncotarget 2: 896-917, 2011.

57. Rattan R, Ali Fehmi R, Munkarah A. Metformin: An emerging new therapeutic option for targeting cancer stem cells and metastasis. J Oncol 928127: 12, 2012. doi: $10.1155 / 2012 / 928127$

58. Eikawa S, Nishida M, Mizukami S, et al. Immune-mediated antitumor effect by type 2 diabetes drug, metformin. Proc Natl Acad Sci USA 112: 1809-1814, 2015.

59. Chae YK, Arya A, Malecek MK, et al. Repurposing metformin for cancer treatment: current clinical studies. Oncotarget 28;7:40767-40780, 2016.

60. Hanna RK, Zhou C, Malloy KM, et al. Metformin potentiates the effects of paclitaxel in endometrial cancer cells through inhibition of cell proliferation and modulation of the mTOR pathway. Gynecol Oncol 125: 458-469, 2012.

61. Storozhuk Y, Hopmans SN, Sanli T, et al. Metformin inhibits growth and enhances radiation response of non-small cell lung cancer (NSCLC) through ATM and AMPK. Br J Cancer 108: 2021-2032, 2013.

62. Cho I, Blaser MJ. The human microbiome: at the interface of health and disease. Nat. Rev. Genet 13: 260-270, 2012.

63. Lee H, Ko G. Effect of metformin on metabolic improvement and gut microbiota. Appl Environ Microbiol 80: 5935-5943, 2014.
64. Maratos-Flier E. Metabolic disease puts up a fight: microbes, metabolism and medications. Nat Med 19: 1218-1219, 2013.

65. Goodwin PJ, Parulekar WR, Gelmon KA, et al. Effect of metformin vs placebo on and metabolic factors in NCIC CTG MA.32. J Natl Cancer Inst 107: 2015. doi: 10.1093/jnci/ djv006

66. Joshua AM, Zannella VE, Downes MR, et al. A pilot 'window of opportunity' neoadjuvant study of metformin in localised prostate cancer. Prostate Cancer Prostatic Dis 17: 252-258, 2014.

67. Lei $Y$, Yi Y, Liu Y, et al. Metformin targets multiple signaling pathways in cancer. Chin J Cancer 36: 17, 2017.

\section{Correspondence:}

Dr. Asli NAR

Bașkent Universitesi Tıp Fakültesi

Endokrinoloji ve Metabolizma Anabilim Dalı

53. Sokak No: 48

06490 Bahcelievler

ANKARA / TURKEY

Tel: $+90-312-2122912$

Fax: $+90-312-2129717$

e-mail: aslinar@hotmail.com 